ARTICLE

\title{
Tuneable separation of gold by selective precipitation using a simple and recyclable diamide
}

\author{
Luke M. M. Kinsman ${ }^{1}$, Bryne T. Ngwenya (1) ${ }^{2}$, Carole A. Morrison (1D ${ }^{1}$ \& Jason B. Love (i) ${ }^{1 凶}$
}

The efficient separation of metals from ores and secondary sources such as electronic waste is necessary to realising circularity in metal supply. Precipitation processes are increasingly popular and are reliant on designing and understanding chemical recognition to achieve selectivity. Here we show that a simple tertiary diamide precipitates gold selectively from aqueous acidic solutions, including from aqua regia solutions of electronic waste. The X-ray crystal structure of the precipitate displays an infinite chain of diamide cations interleaved with tetrachloridoaurate. Gold is released from the precipitate on contact with water, enabling ligand recycling. The diamide is highly selective, with its addition to 29 metals in $2 \mathrm{M} \mathrm{HCl}$ resulting in $70 \%$ gold uptake and minimal removal of other metals. At $6 \mathrm{M} \mathrm{HCl}$, complete collection of gold, iron, tin, and platinum occurs, demonstrating that adaptable selective metal precipitation is controlled by just one variable. This discovery could be exploited in metal refining and recycling processes due to its tuneable selectivity under different leaching conditions, the avoidance of organic solvents inherent to biphasic extraction, and the straightforward recycling of the precipitant.

\footnotetext{
${ }^{1}$ EaStCHEM School of Chemistry, University of Edinburgh, Edinburgh EH9 3FJ, UK. ${ }^{2}$ School of Geosciences, University of Edinburgh, Edinburgh EH9 3FE, UK.

凶email: jason.love@ed.ac.uk
} 
T he extraction of gold from its ores and its recycling from waste materials represent significant technological and environmental challenges ${ }^{1-4}$. Alternatives to the current industrial practice of cyanidation ${ }^{5,6}$ and informal mercury alloying 7,8 that are based upon selective extraction, precipitation, or adsorption of gold from leach solutions are being actively pursued $^{9}$, with the recycling of electronic waste (e-waste) the focus of much attention as it presents a significantly higher concentration of gold than its ores ${ }^{10}$. Recycling these latter materials would also provide impetus to global circular economy visions ${ }^{11,12}$, but their complexity requires highly selective and environmentally benign recycling technologies ${ }^{13,14}$.

Selective and reusable precipitation and adsorption methods are becoming increasingly popular for gold and other metal separations as they provide significant advantages over traditional, single-use precipitants ${ }^{15-19}$. Pre-formed porous network materials such as metal-organic frameworks (MOFs), polymers, and electroactive materials are selective for gold adsorption, and often exploit the accessible reduction potential of gold to deposit the metal within the porous cavities ${ }^{20-25}$. Molecular recognition processes involving cyclodextrins ${ }^{26,27}$ and cucurbit $[n]$ urils $(n=5-8)^{28-30}$ use the curvature and donor-group decoration of these capsular guest molecules to host selectively both alkalimetal cations and $\mathrm{AuCl}_{4}{ }^{-}$within superstructures that ultimately precipitate gold from aqueous acidic solutions. This rationale has also been extended to the separation by precipitation of platinum from palladium and rhodium in which the cucurbituril displays a preference for the hexachloroplatinate(IV) dianion ${ }^{31}$. Supramolecular interactions between acyclic durene diamides and $\mathrm{HAuCl}_{4}$ resulted in gold precipitation as extended networks, although in these cases no selectivity for gold over other metals was explored $^{32}$. Extended supramolecular network structures were also formed upon selective precipitation of $\mathrm{HAuCl}_{4}$ from acidic solutions comprising $\mathrm{Au}, \mathrm{Ni}, \mathrm{Cu}, \mathrm{Zn}$, alkali-, and alkaline-earth metals by the biomolecule niacin, a pyridine carboxylic acid ${ }^{33}$.

We reported that simple monoamides showed high selectivity in the separation of gold by solvent extraction (SX) from acidic solutions of metals representative of e-waste ${ }^{34,35}$. Protonation of the monoamides formed intermolecular proton-chelated receptor cations in the organic phase that dynamically assembled with $\mathrm{AuCl}_{4}{ }^{-}$into supramolecular clusters. In some cases, mixed-metal third phases formed, along with a tin-containing precipitate ${ }^{35}$. The observation of proton-linked amides by us and others in gold separations suggested that the simple diamide (L) (Fig. 1a) would readily assemble into a proton-chelated structure suitable for metalate recognition along with a potential to form insoluble, infinitely extended structures. A resulting selective precipitation could both eradicate the use of potentially hazardous organic solvents in SX separations and simplify a hydrometallurgical separation process. Here we show that diamide L acts as a highly selective reagent for the precipitation of gold from a variety of aqueous acidic solutions and, by tuning the $\mathrm{HCl}$ concentration, allows other valuable and critical metals to be separated by precipitation.

\section{Results and discussion}

Precipitation experiments. Initial screening of $\mathrm{L}$ in SX experiments showed fast gold transport from $2 \mathrm{M}$ and $6 \mathrm{M} \mathrm{HCl}$ to form yellow chloroform phases but, as desired and in contrast to previous results ${ }^{35}$, yellow precipitates form that contain all of the gold. The diamide $\mathrm{L}$ was therefore evaluated as a precipitant in the absence of the organic solvent (Fig. 1). Adding $0.2 \mathrm{mmol}$ of solid $\mathrm{L}$, the equivalent in moles used in the SX experiments (i.e., a 10 -fold excess), to a $0.01 \mathrm{M} \mathrm{HAuCl}_{4}$ solution in $2 \mathrm{M}$ or $6 \mathrm{M} \mathrm{HCl}$ results in colourless supernatants and yellow solids which incorporate $>99 \%$ of the gold. Analysis of these supernatants by ICP-MS shows residual gold concentrations of $5.9 \mathrm{ppm}$ and $2.3 \mathrm{ppm}$ in $2 \mathrm{M}$ and $6 \mathrm{M} \mathrm{HCl}$, respectively (Supplementary Table 1). Repeating these experiments using significantly more dilute Au solutions (10 ppm) results in $89 \%$ and $84 \%$ Au precipitation from $2 \mathrm{M}$ and $6 \mathrm{M} \mathrm{HCl}$ solutions, respectively, with residual gold concentrations of approximately $1 \mathrm{ppm}$ in the supernatants. Furthermore, complete gold precipitation using $\mathrm{L}$ is also seen from solutions of $\mathrm{HAuCl}_{4}$ in 20 or $100 \%$ aqua regia or $2 \mathrm{M} \mathrm{H}_{2} \mathrm{SO}_{4}$ in the presence of chloride or bromide (Supplementary Table 1), indicating that the process should be suited for a range of leaching conditions. Moreover, the use of precipitation instead of SX overcomes safety and environmental issues inherent with the use of organic solvents on a large scale. Significantly, the release of gold from the isolated solids is achieved by washing with deionised (DI) water, resulting in transport of $\mathrm{HAuCl}_{4}$ into solution and the recycling of L (Supplementary Table 2). The recycled diamide can be used in further gold load/strip cycles showing $87 \%$ loading efficacy after three cycles (Supplementary Information, Table 3); this decrease from the initial $99 \%$ gold precipitation after three cycles is likely due to sampling errors while handling milligram quantities of the diamide.

Selectivity of precipitation. The uptake of gold by L from mixtures of metals in $\mathrm{HCl}$ is highly selective. The addition of $0.2 \mathrm{mmol}$ of solid $\mathrm{L}$ to a mixed-metal solution comprising $0.01 \mathrm{M}$ each of $\mathrm{Au}, \mathrm{Al}, \mathrm{Cu}, \mathrm{Ni}, \mathrm{Fe}, \mathrm{Zn}, \mathrm{Pt}, \mathrm{Pd}$, and $\mathrm{Sn}$ in $2 \mathrm{M} \mathrm{HCl}$ results in near quantitative removal of Au with minimal co-precipitation of other metals ( $<5 \%$, Fig. $1 \mathrm{~b}$, orange bars). It is notable that using stoichiometric L results in gold uptake only (i.e., $0.02 \mathrm{mmol}$, Fig. 1b, green bars) which contrasts with SX conditions where an excess of extractant is required, thus highlighting the enhanced atom economy of this precipitation method. At $6 \mathrm{M} \mathrm{HCl}$ using excess $\mathrm{L}$, complete uptake of $\mathrm{Fe}, \mathrm{Sn}$, and $\mathrm{Pt}$ is also seen, alongside $\mathrm{Au}$, from the above mixture of metals (Fig. 1b, blue bars), and is likely due to an increased propensity to form the chloridometalates $\mathrm{FeCl}_{4}^{-}, \mathrm{SnCl}_{6}^{2-}$, and $\mathrm{PtCl}_{6}^{2-}$ at higher $\mathrm{HCl}$ concentrations. Using stoichiometric L, however, a return to selective gold uptake is seen (Fig. 1b, yellow bars), which shows that a process could be designed to sequentially precipitate $\mathrm{Au}$ then, depending on the feed stream, Fe, Sn, or Pt. This is significant as leach solutions from gold ores (typically pyrite or arsenopyrite) are rich in iron, while those derived from e-waste have high concentrations of $\operatorname{tin}^{36}$. Furthermore, the selectivity shown between $\mathrm{Pt}(\mathrm{IV})$ and $\mathrm{Pd}(\mathrm{II})$ at $6 \mathrm{M} \mathrm{HCl}$ is notable as this separation is integral to precious metal refining processes currently based on $\mathrm{SX}^{37}$. The selectivity seen under stoichiometric conditions also suggests that the preference for gold precipitation is not wholly dependent on the ease of formation of $\mathrm{HAuCl}_{4}$ compared with other chloridometalates, but that the chemical structures of the precipitates also define the sequence of separation (see structural analysis later).

The selective uptake of $\mathrm{Au}$ at $2 \mathrm{M} \mathrm{HCl}$ compared with the requirement for $6 \mathrm{M} \mathrm{HCl}$ to load $\mathrm{Fe}, \mathrm{Sn}$, and Pt permits a selective stripping process to be undertaken. As such, loading $\mathrm{L}$ with $\mathrm{Au}$, $\mathrm{Fe}$, Pt, and $\mathrm{Sn}$ at $6 \mathrm{M} \mathrm{HCl}$ (Fig. 1c, blue bars), followed by a wash with $2 \mathrm{M} \mathrm{HCl}$ results in dissolution of $\mathrm{Fe}, \mathrm{Sn}$, and Pt only, with $\mathrm{Au}$ retained on the solids (Fig. 1c, green bars). Washing the isolated solids with DI water releases the Au into solution and recycles L (Fig. 1c, yellow bars). Reduction of this solution by sodium metabisulfite yields metallic gold of $97.04 \%$ purity (Supplementary Table 4).

The selectivity of $\mathrm{L}$ for Au uptake was evaluated further by adding an excess to mixed-metal ICP-OES standard solutions (diluted in $2 \mathrm{M}$ or $6 \mathrm{M} \mathrm{HCl}$ ), comprising 29 metals at 100 or 


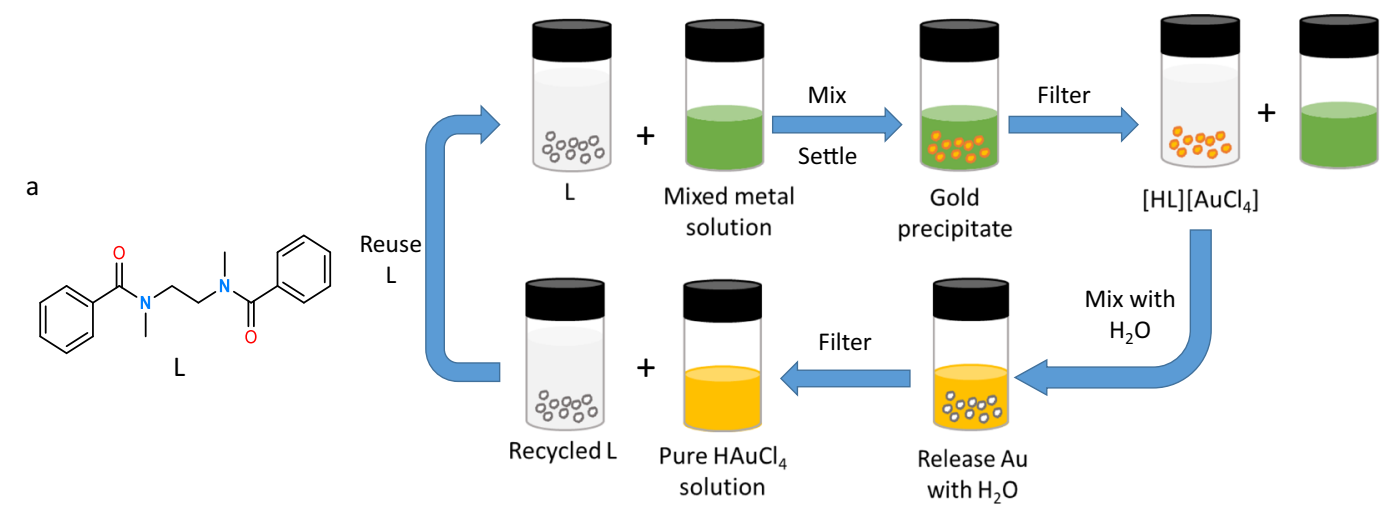

b

c
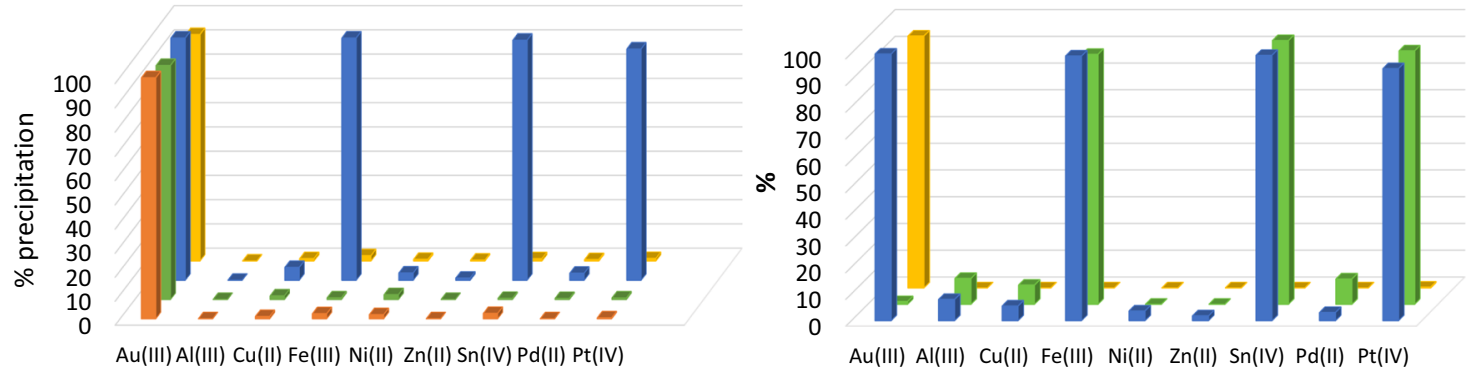

Fig. 1 Schematic of the precipitation process and its selectivity. a Chemical structure of $L$ and schematic of the precipitation process. $\mathbf{b}$ Percentage metal(s) removed by precipitation from a $0.01 \mathrm{M}$ mixed-metal solution in $2 \mathrm{M}$ (orange and green bars) or $6 \mathrm{M}$ (blue and yellow bars) $\mathrm{HCl}$ following the addition of either $0.2 \mathrm{mmol} \mathrm{L}$ (10-fold excess $\mathrm{L}$ relative to metal, orange and blue bars) or $0.02 \mathrm{mmol} \mathrm{L}$ (equimolar, green and yellow bars). c Selective metal precipitation and stripping sequence. Blue bars: Percentage metal removed by precipitation from a $0.01 \mathrm{M}$ mixed-metal solution in $6 \mathrm{M} \mathrm{HCl}$. Green bars: percentage of metal stripped from the precipitate by a $2 \mathrm{M} \mathrm{HCl}$ wash. Yellow bars: percentage of metal stripped from the precipitate after a subsequent wash with deionised water. Experiments carried out in triplicate.

$10 \mathrm{ppm}$ concentrations. Analysis of the concentrations of metals that remain in solution reveals that even in this competitive environment, $\mathrm{L}$ is highly selective for gold, with $70 \%$ uptake after $24 \mathrm{~h}$ (Supplementary Fig. 1). Raising the concentration of $\mathrm{HCl}$ to $6 \mathrm{M}$ increases the uptake of $\mathrm{Au}$ to $>99 \%$ but decreases selectivity, with $\mathrm{Tl}$ (95\%), Ga (>99\%), and $\mathrm{Fe}(70 \%)$ also precipitated; however, these metals could in principle be removed from the precipitate by a $2 \mathrm{M} \mathrm{HCl}$ wash (see above). Interestingly, no $\mathrm{Pt}$ uptake is seen and is due to it being present as $\mathrm{Pt}(\mathrm{II})$ (i.e., $\mathrm{PtCl}_{4}{ }^{2-}$ ) and not $\mathrm{Pt}(\mathrm{IV})$ (i.e., $\mathrm{PtCl}_{6}{ }^{2-}$ ), showing that the structure of the chloridometalate is important to the precipitation process.

Finally, gold was selectively separated from end-of-life printed circuit boards dissolved in aqua regia (diluted to $40 \%$ ), with $98 \% \mathrm{Au}$ precipitation after $1 \mathrm{~h}$ and no co-precipitation of any of the other elements present (Supplementary Table 5 and Supplementary Fig. 2). This contrasts with SX experiments using secondary and tertiary monoamides that formed a dense organic third phase comprising gold, iron, and tin on contact with model e-waste solutions ${ }^{35}$.

Structural analysis of precipitates. Layering a solution of $0.01 \mathrm{M}$ $\mathrm{HAuCl}_{4}$ in $2 \mathrm{M} \mathrm{HCl}$ on a $0.1 \mathrm{M}$ chloroform solution of $\mathrm{L}$ results in controlled crystallisation. The X-ray crystal structure (Fig. 2a) shows a chemical formula of $[\mathrm{HL}]\left[\mathrm{AuCl}_{4}\right]$ in which the unique proton $\mathrm{H} 1$ is bound between adjacent amide $\mathrm{O}$-atoms $\mathrm{O} 1$ and O1a (O1-O1a $=2.420(3) \AA$ ), forming an intermolecular proton chelate between amide units that assemble into an infinite supramolecular chain motif. While the linking of the diamides in $[\mathrm{HL}]\left[\mathrm{AuCl}_{4}\right]$ is similar to that seen for $\mathrm{HAuCl}_{4}$ complexes of the diamidodurene $\mathrm{R}^{\prime} \mathrm{C}(\mathrm{O}) \mathrm{N}(\mathrm{R}) \mathrm{CH}_{2}\left(\mathrm{C}_{6} \mathrm{Me}_{4}\right) \mathrm{CH}_{2} \mathrm{~N}(\mathrm{R}) \mathrm{C}(\mathrm{O}) \mathrm{R}^{\prime 32}$, the positioning of the anions is different. In the latter example, the $\pi$ rich aryl group interacts strongly through face-to-face $\pi$-bonding with the planar $\mathrm{AuCl}_{4}^{-}$, whereas for $[\mathrm{HL}]\left[\mathrm{AuCl}_{4}\right]$ the phenyl and methyl substituents within the ribbon-like structure of the protonated diamides provide rhombohedral clefts that host the $\mathrm{AuCl}_{4}^{-}$guest. A non-covalent interaction (NCI) plot (Fig. 3) shows that the ligand clefts provide stabilising van der Waal interactions through the aryl ring and amide linkage, alongside multiple non-classical $\mathrm{C}-\mathrm{H}$-..Cl hydrogen-bonding contacts.

Crystallisations of $[\mathrm{HL}]_{2}\left[\mathrm{PtCl}_{6}\right],[\mathrm{HL}]\left[\mathrm{FeCl}_{4}\right]$, and $[\mathrm{HL}]_{2}\left[\mathrm{SnCl}_{6}\right]$ were also achieved (Fig. $2 \mathrm{~b}$ and Supplementary Fig. 4a, b, respectively). All three complexes are structurally similar, adopting a ribbon motif of $[\mathrm{HL}]^{+}$with an intermolecular proton chelate analogous to that seen for $[\mathrm{HL}]\left[\mathrm{AuCl}_{4}\right]$. This results in a similar rhombohedral cavity which accommodates $\left[\mathrm{FeCl}_{4}\right]^{-}$but which is offset in the structures of $[\mathrm{HL}]_{2}\left[\mathrm{SnCl}_{6}\right]$ and $[\mathrm{HL}]_{2}\left[\mathrm{PtCl}_{6}\right]$, the latter two structures also accommodating one molecule of water per asymmetric unit. The $\mathrm{N}-\mathrm{C}-\mathrm{C}-\mathrm{N}$ torsion angle of the diamide bridge varies according to the metalate and is significantly smaller for $\mathrm{Au}\left(54.0^{\circ}\right)$ than the other metals (Fe: 81.0/88.2; Sn 80.0; Pt $80.6^{\circ}$ ). The NCI plots (Fig. 3 and Supplementary Fig. 3 ) reveal that the nature of the host-guest interactions switches to $\mathrm{C}-\mathrm{H} \cdots \mathrm{Cl}$, with the water molecule in the $[\mathrm{HL}]_{2}\left[\mathrm{SnCl}_{6}\right]$ and $[\mathrm{HL}]_{2}\left[\mathrm{PtCl}_{6}\right]$ structures providing additional non-classical hydrogen-bonding to both the ligand and metalate ions. The host/guest interactions in these complexes are of a stronger nature (more negative $\rho$ ) compared with [HL] $\left[\mathrm{AuCl}_{4}\right]$.

Metals such as cobalt and zinc that are not precipitated by $\mathrm{L}$ remain in solution. However, at $10 \mathrm{M} \mathrm{HCl}$, a concentration at which L is completely soluble, some crystallisation occurs and the X-ray crystal structures show the formation of $[\mathrm{HL}]\left[\mathrm{H}_{3} \mathrm{O}\left(\mathrm{H}_{2} \mathrm{O}\right)_{2}\right]$ $\left[\mathrm{CoCl}_{4}\right]$ (Fig. 2c) and [HL] $\left[\mathrm{H}_{3} \mathrm{O}\left(\mathrm{H}_{2} \mathrm{O}\right)_{2}\right]\left[\mathrm{ZnCl}_{4}\right]$ (Supplementary Fig. $4 \mathrm{c})$. In both cases, $[\mathrm{HL}]^{+}$forms an infinite intermolecular proton-chelated motif, with $\mathrm{N}-\mathrm{C}-\mathrm{C}-\mathrm{N}$ torsional angles of 72.5 
a
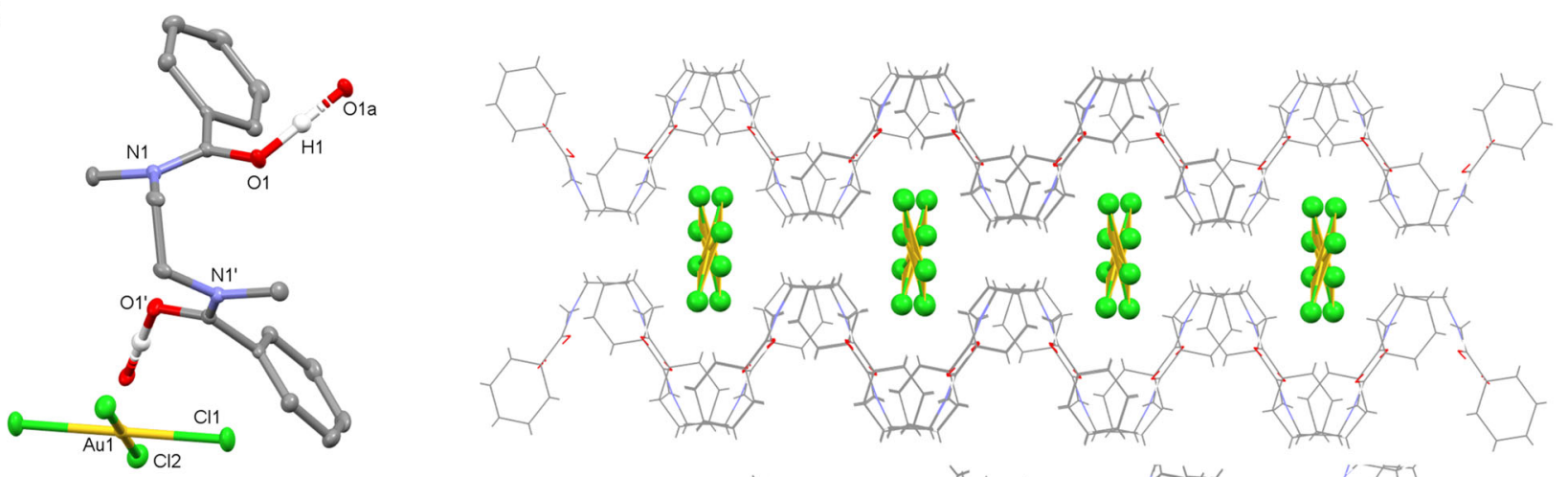

b
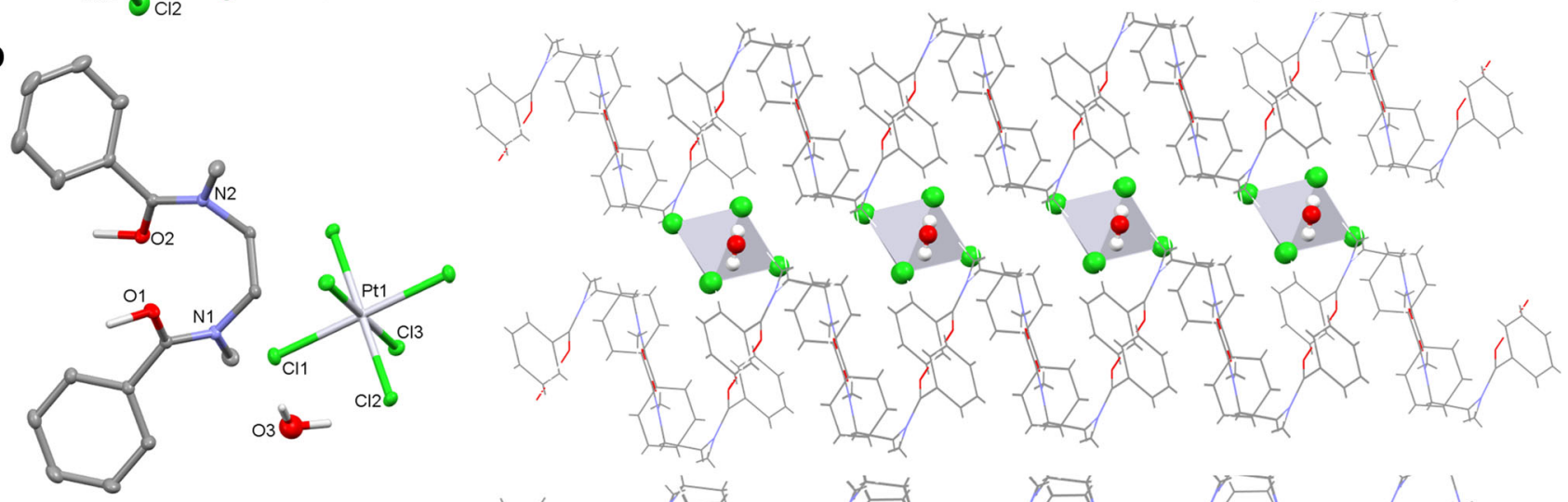

C
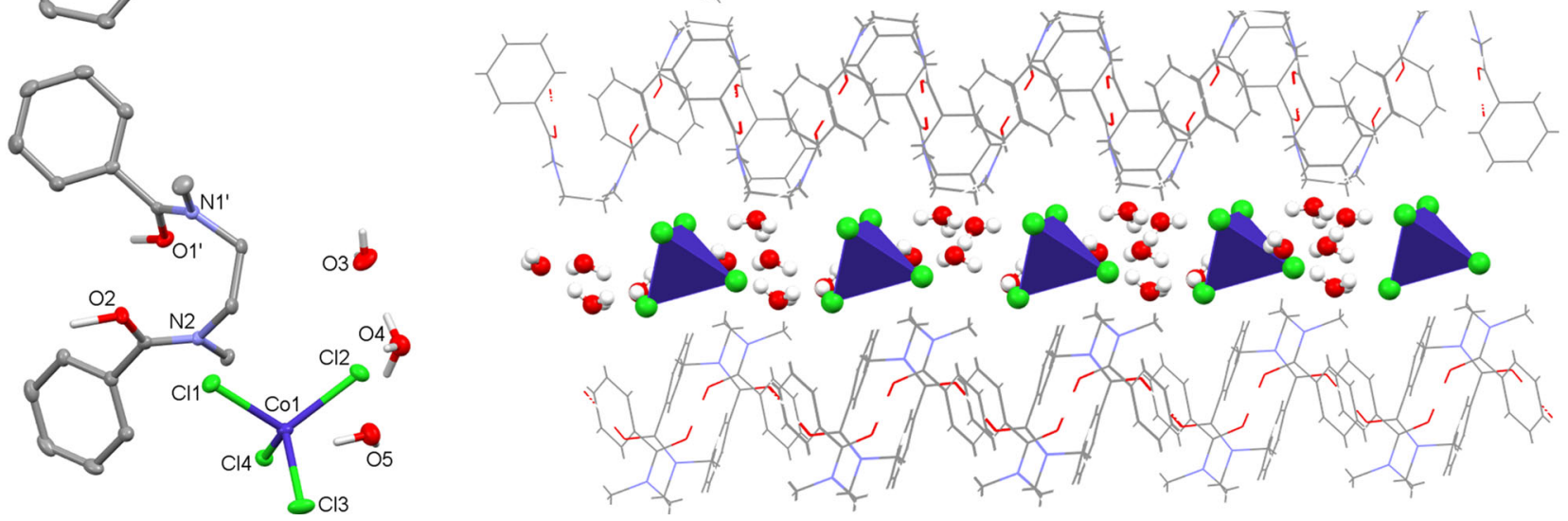

Fig. 2 Structural characterisation of precipitates by X-ray crystallography. For clarity, all hydrogens except those involved in hydrogen bonding are omitted (displacement ellipsoids are drawn at 50\% probability). Atom colours: red $=\mathrm{O}$; cyan $=\mathrm{N}$; grey $=\mathrm{C}$; green $=\mathrm{Cl}$; yellow $=\mathrm{Au}$, pale grey $=\mathrm{Pt}$, dark blue $=\mathrm{Co}$; white $=\mathrm{H}$. a X-ray crystal structure of $[\mathrm{HL}]\left[\mathrm{AuCl}_{4}\right]$ showing the intermolecular proton-chelate structure and the arrangement of $\mathrm{AuCl}_{4}{ }^{-}$within the rhombohedral clefts derived from the phenyl and methyl substituents of the infinite chain of protonated diamides, $\mathrm{C}(\mathrm{H})-\mathrm{Cl}(\mathrm{Au}) 3.43-3.97 \AA ; \mathrm{N1}-\mathrm{C} 3-$ $\mathrm{C}^{\prime}-\mathrm{N}^{\prime} 54.9(3)^{\circ}$. b X-ray crystal structure of $\left[\mathrm{HL}_{2}\left[\mathrm{PtCl}_{6}\right]\left(\mathrm{H}_{2} \mathrm{O}\right)\right.$ showing the arrangement of $\mathrm{PtCl}_{6}{ }^{2-}$ and a molecule of water within the intermolecular proton-chelated structure. For clarity, only one of the two $[\mathrm{HL}]$ cations is shown. $\mathbf{c} X$-ray crystal structure of $[\mathrm{HL}]\left[\mathrm{H}_{3} \mathrm{O}\left(\mathrm{H}_{2} \mathrm{O}\right)_{2}\right]\left[\mathrm{CoCl}{ }_{4}\right]$ showing the intermolecular proton-chelate structure and the layered arrangement of $\mathrm{CoCl}_{4}{ }^{2-}$ and $\mathrm{H}_{3} \mathrm{O}^{+}$water cluster between the infinite ribbon chain of protonated diamides.

and $72.6^{\circ}$ for $\mathrm{Co}$ and $\mathrm{Zn}$, respectively. Protonated water clusters $\left[\mathrm{H}_{3} \mathrm{O}\left(\mathrm{H}_{2} \mathrm{O}\right)_{2}\right]^{+}$are found instead of a second $[\mathrm{HL}]^{+}$, resulting in well-defined layers of $\left[\mathrm{H}_{3} \mathrm{O}\left(\mathrm{H}_{2} \mathrm{O}\right)_{2}\right]^{+} /\left[\mathrm{MCl}_{4}\right]^{2-}$ interleaved with $[\mathrm{HL}]^{+}$. The NCI plots (Fig. 3 and Supplementary Fig. 3) again support $\mathrm{C}-\mathrm{H} \cdots \mathrm{Cl}$ host/guest interactions, bridged with nonclassical hydrogen-bonding from the protonated water clusters. Thus, it can be concluded that distinct structural differences exist between the complexes that readily precipitate from aqueous acid compared with those that do not. There is also a marked preference for $[\mathrm{HL}]^{+} /$metalate ion-pair formation in the solid state, even under the highly biased relative concentrations of metalate $(0.01 \mathrm{M})$ vs. chloride $(2-10 \mathrm{M} \mathrm{HCl})$, which has favourable implications for process mass balance.
Mechanism of precipitation. The discovery that full uptake of gold from solution occurs using a stoichiometric amount of $\mathrm{L}$ suggests that a dissolution-precipitation, not a surface-deposition mechanism, is occurring. This is supported by analysis of the rate of gold uptake at various concentrations of $\mathrm{HCl}$ (Supplementary Figs. 5 and 6), which is found to be related to the extent of dissolution of L. Addition of $\mathrm{HAuCl}_{4}$ to a solution of $\mathrm{L}$ in $12 \mathrm{M}$ $\mathrm{HCl}$ results in the rapid and wholesale precipitation of [HL] $\left[\mathrm{AuCl}_{4}\right]$. Dissolution of $\mathrm{L}$ in $2 \mathrm{M} \mathrm{HCl}$, as determined by quantitative ${ }^{1} \mathrm{H}$ NMR spectroscopy, is minimal at $0.6 \mathrm{mM}$, while heating this solution to $340 \mathrm{~K}$ increases the concentration of dissolved $\mathrm{L}$ to $0.8 \mathrm{mM}$ (Supplementary Fig. 7, Supplementary Table 6). Increasing the concentration of $\mathrm{HCl}$ to $6 \mathrm{M}$ results in a 15-fold 

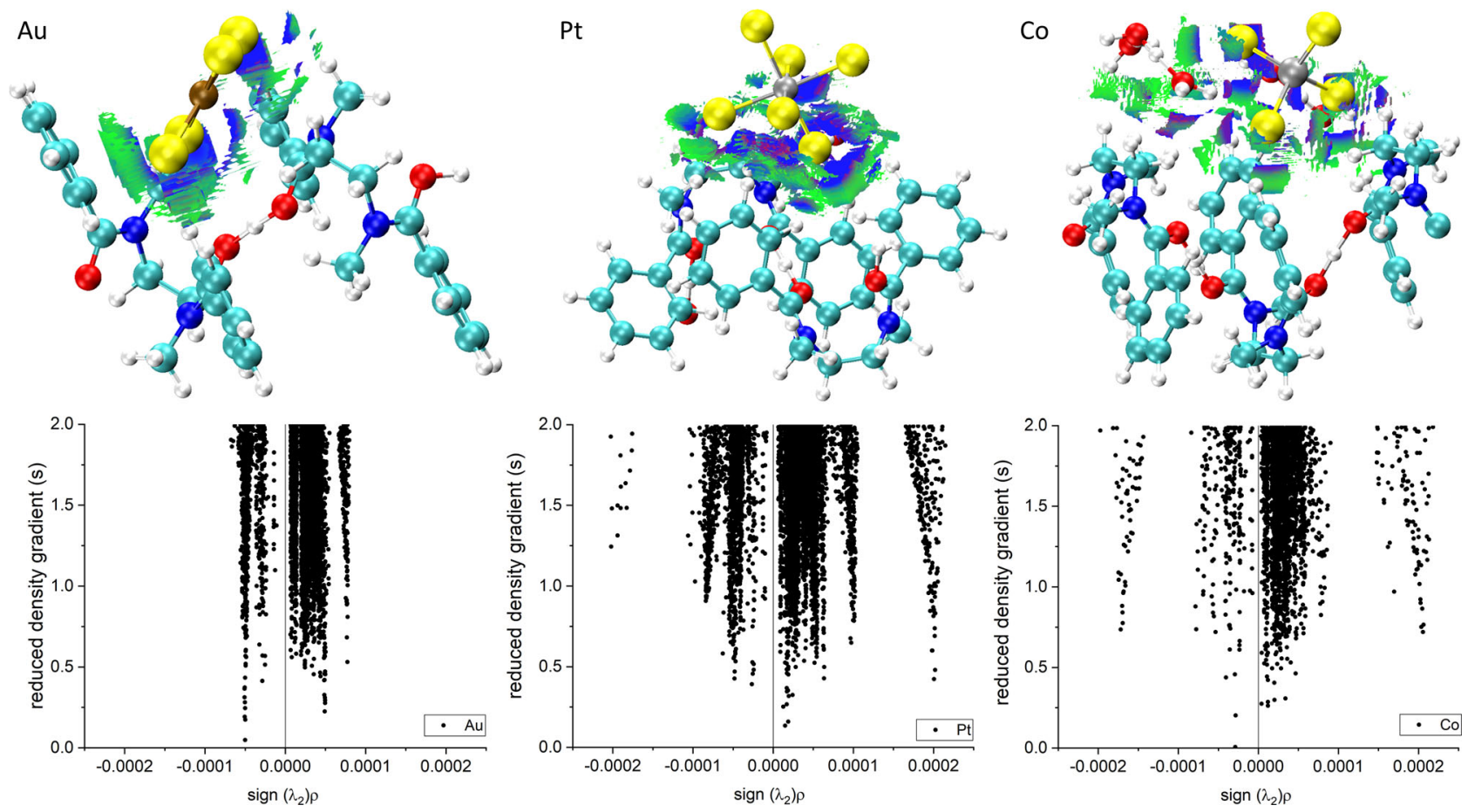

Fig. 3 Non-covalent interaction $(\mathbf{N C l})$ analysis. Non-covalent bonding interactions 3D isosurface plots $(s=1.0$ au, -0.00025 (dark blue scale) $<\rho<0$ (green scale) au) (top), and $2 \mathrm{D} \rho$ vs s plots (bottom) for the crystal structures of $[\mathrm{HL}]\left[\mathrm{AuCl}_{4}\right],\left[\mathrm{HL}_{2}\left[\mathrm{PtCl}_{6}\right] \cdot \mathrm{H}_{2} \mathrm{O}\right.$, and $[\mathrm{HL}]\left[\mathrm{H}_{3} \mathrm{O}\left(\mathrm{H}_{2} \mathrm{O}\right)_{2}\right]\left[\mathrm{CoCl} l_{4}\right] . \mathrm{Atom}$ colours: cyan $=\mathrm{C}$, red $=\mathrm{O}$, dark blue $=\mathrm{N}$; yellow $=\mathrm{Cl}$; white $=\mathrm{H}$; brown $=\mathrm{Au}$; grey $=\mathrm{Pt}$ or Co.

increase to $8.7 \mathrm{mM}$ at $300 \mathrm{~K}$ (Supplementary Fig. 8, Supplementary Table 7). The increase in dissolved $\mathrm{L}$ mirrors the increase in quantity of $[\mathrm{HL}]\left[\mathrm{AuCl}_{4}\right]$ precipitated from $2 \mathrm{M} \mathrm{HCl}$ over $5 \mathrm{~min}$, which doubles on raising the temperature from 20 to $40{ }^{\circ} \mathrm{C}$ and from 40 to $80^{\circ} \mathrm{C}$ (Supplementary Fig. 9).

The precipitate from the addition of $0.02 \mathrm{mmol}$ of $\mathrm{L}$ to a solution of $0.01 \mathrm{M} \mathrm{HAuCl}_{4}$ in $6 \mathrm{M} \mathrm{HCl}$ was analysed by powder X-ray diffraction (Supplementary Fig. 10) and showed the presence of two phases commensurate with a mixture of microcrystalline [HL] $\left[\mathrm{AuCl}_{4}\right]$ and $\mathrm{L}$. Refinement of the unit cell parameters in space group $I 2 / a(a=12.216(1) \AA, b=17.099(5) \AA, c=16.721$ (3) $\AA$, $\beta=142.79$ (1) ${ }^{\circ}$ ) shows a close match with those of the singlecrystal X-ray data for $[\mathrm{HL}]\left[\mathrm{AuCl}_{4}\right] \quad(a=12.0848(7) \AA$, $\left.b=16.9574(2) \AA, c=16.5644(10) \AA, \beta=142.07(1)^{\circ}\right)$, further supporting a dissolution-precipitation mechanism.

We have shown that a simple diamide acts as a very selective and recyclable precipitant for gold under a variety of conditions relevant to metal separation processes. Metal uptake is tuneable and related to the acidity of the leach solution and the structures of the precipitates, allowing for further tailoring of these compounds to target different metal separations. The use of this highly selective and recyclable precipitation method precludes the use of organic solvents inherent to SX separations and may provide a simple solution towards environmentally benign metal recycling.

\section{Methods}

All solvents and reagents were used as received from Sigma-Aldrich, Fisher Scientific UK, Alfa Aesar, Acros Organics or VWR International. Deionised water was obtained from a MilliQ purification system.

Synthesis of $\mathbf{L}$. Diamide $\mathbf{L}$ was prepared according to a procedure adapted from the literature ${ }^{38}$. Under argon, $\mathrm{N}^{\prime} \mathrm{N}^{\prime}$-dimethylethylenediamine $(1.76 \mathrm{~g}, 2.15 \mathrm{~mL}$, $20 \mathrm{mmol})$ was dissolved in $\mathrm{CH}_{2} \mathrm{Cl}_{2}(30 \mathrm{~mL})$ and treated with $\mathrm{NEt}_{3}(7 \mathrm{~mL})$. A solution of benzoyl chloride $(7.03 \mathrm{~g}, 5.81 \mathrm{~mL}, 50 \mathrm{mmol})$ in $\mathrm{CH}_{2} \mathrm{Cl}_{2}(20 \mathrm{~mL})$ was slowly added and the resulting solution stirred at r.t. for $18 \mathrm{~h}$. The solution was then diluted with $\mathrm{CH}_{2} \mathrm{Cl}_{2}(50 \mathrm{~mL})$ and washed with $1 \mathrm{M} \mathrm{HCl}(3 \times 100 \mathrm{~mL})$ and brine $(3 \times 100 \mathrm{~mL})$. The organic layer was dried over sodium sulfate and evaporated to dryness under vacuum. The resulting solid was recrystalised from hot toluene to yield $\mathrm{L}$ as a white powder $(4.54 \mathrm{~g}, 77 \%)$.

Precipitation procedure for $0.01 \mathrm{M}$ mixed metal solutions. Hydrochloric acid solutions $(2 \mathrm{M}$ and $6 \mathrm{M})$ were prepared by dilution of concentrated hydrochloric acid with deionised water. Mixed-metal solutions $(0.01 \mathrm{M})$ were typically prepared by dilution of $0.1 \mathrm{M}$ stock solutions of each individual metal salt solution in 2 or $6 \mathrm{M} \mathrm{HCl}$. The resulting $\mathrm{pHs}$ of all solutions were recorded as zero. Solid L $(0.2 \mathrm{mmol}$ or $0.02 \mathrm{mmol})$ was added to a vial with a magnetic stir bar and the metal-containing aqueous solution $(2 \mathrm{~mL})$ added. The mixture was stirred for $1 \mathrm{~h}$ at room temperature $\left(20^{\circ} \mathrm{C}\right)$ at $500 \mathrm{rpm}$ after which the stir bar was removed and the vial centrifuged. The supernatant was decanted and samples prepared for ICP-OES analysis to measure the uptake of metal by L. Samples were diluted by 100x in $2 \%$ nitric acid prior to ICP-OES analysis. This procedure was repeated in triplicate.

Selective precipitation of gold from 28 other elements procedure. The following ICP multi-element standard solutions were used: Transition metal mix 3 for ICP supplied by Sigma Aldrich comprising $100 \mathrm{mg} \mathrm{L}^{-1} \mathrm{Au}$, Ir, Os, Pd, Pt, Rh, Ru in $10 \%$ hydrochloric acid and ICP multi-element standard solution IV comprising $1000 \mathrm{mg} \mathrm{L}^{-1} \mathrm{Ag}, \mathrm{Al}, \mathrm{B}, \mathrm{Ba}, \mathrm{Bi}, \mathrm{Ca}, \mathrm{Cd}, \mathrm{Co}, \mathrm{Cr}, \mathrm{Cu}, \mathrm{Fe}, \mathrm{Ga}, \mathrm{In}, \mathrm{K}, \mathrm{Li}, \mathrm{Mg}, \mathrm{Mn}, \mathrm{Na}$, $\mathrm{Ni}, \mathrm{Pb}, \mathrm{Sr}, \mathrm{Tl}, \mathrm{Zn}$ in dilute nitric acid. Each solution $(1 \mathrm{~mL})$ was diluted to $10 \mathrm{~mL}$ using either $2 \mathrm{M} \mathrm{HCl}$ or $6 \mathrm{M} \mathrm{HCl}$, resulting in solutions of $10 \mathrm{mg} \mathrm{L}^{-1} \mathrm{Au}, \mathrm{Ir}$, Os, $\mathrm{Pd}, \mathrm{Pt}, \mathrm{Rh}, \mathrm{Ru}$ and $100 \mathrm{mg} \mathrm{L}^{-1} \mathrm{Al}, \mathrm{B}, \mathrm{Ba}, \mathrm{Bi}, \mathrm{Ca}, \mathrm{Cd}, \mathrm{Co}, \mathrm{Cr}, \mathrm{Cu}, \mathrm{Fe}, \mathrm{Ga}, \mathrm{In}, \mathrm{K}, \mathrm{Li}$, $\mathrm{Mg}, \mathrm{Mn}, \mathrm{Na}, \mathrm{Ni}, \mathrm{Pb}, \mathrm{Sr}, \mathrm{Tl}, \mathrm{Zn}$. The solutions were filtered prior to use in precipitation experiments due to the precipitation of silver chloride, which was subsequently excluded from ICP-OES analysis. The precipitation method used for the $0.01 \mathrm{M}$ mixed-metal solutions was followed.

Selective precipitation of gold from waste printed circuit boards. End-of-life printed circuit boards were supplied by Edinburgh School of Chemistry workshop. Gold-tipped sections of the circuit boards $(22.85 \mathrm{~g})$ were cut off and soaked in $100 \mathrm{~mL}$ aqua regia for $24 \mathrm{~h}$. This solution was then diluted with deionised water to $250 \mathrm{~mL}$ and the metal content analysed by ICP-OES. An aliquot of the e-waste solution $(2 \mathrm{~mL})$ was stirred with $\mathrm{L}(0.0059 \mathrm{~g}, 0.02 \mathrm{mmol}$, excess with respect to the gold concentration) for $1 \mathrm{~h}$ at room temperature after which the stir bar was removed and the vial centrifuged. The supernatant was decanted and samples prepared for ICPOES analysis to measure the uptake of metal. Samples were diluted by 1000x and 20x in $2 \%$ nitric acid prior to ICP-OES analysis. This procedure was repeated in triplicate.

Crystallisation procedures. $[\mathrm{HL}]\left[\mathrm{AuCl}_{4}\right]$ : Light yellow prisms were grown at RT from a $0.01 \mathrm{M}$ solution of $\mathrm{HAuCl}_{4}$ in $2 \mathrm{M} \mathrm{HCl}$ layered on a $0.1 \mathrm{M}$ solution of $\mathrm{L}$ in chloroform. [HL][ $\left.\mathrm{FeCl}_{4}\right]$ : Yellow needles were grown at RT from a $0.01 \mathrm{M}$ solution 
of $\mathrm{FeCl}_{3}$ in $6 \mathrm{M} \mathrm{HCl}$ layered on a $0.1 \mathrm{M}$ solution of $\mathrm{L}$ in chloroform. $[\mathrm{HL}]_{2}\left[\mathrm{SnCl}_{6}\right]$ $\left(\mathrm{H}_{2} \mathrm{O}\right)$ : Colourless plates were grown from a $0.01 \mathrm{M}$ solution of $\mathrm{SnCl}_{4}$ in $6 \mathrm{M} \mathrm{HCl}$ layered on a $0.1 \mathrm{M}$ solution of $\mathrm{L}$ in chloroform. $[\mathrm{HL}]_{2}\left[\mathrm{PtCl}_{6}\right]\left(\mathrm{H}_{2} \mathrm{O}\right)$ : Yellow/orange slabs were grown from a mixture of $0.01 \mathrm{M} \mathrm{Na}_{2} \mathrm{PtCl}_{6}$ and $\mathrm{L}$ in $6 \mathrm{M} \mathrm{HCl}$. [HL] $\left[\mathrm{H}_{3} \mathrm{O}\left(\mathrm{H}_{2} \mathrm{O}\right)_{2}\right]\left[\mathrm{CoCl}_{4}\right]$ : Translucent dark blue plates were grown at RT from a mixture of $0.01 \mathrm{M} \mathrm{CoCl}_{2}$ and $\mathrm{L}$ in $10 \mathrm{M} \mathrm{HCl}$. [HL] $\left[\mathrm{H}_{3} \mathrm{O}\left(\mathrm{H}_{2} \mathrm{O}\right)_{2}\right]\left[\mathrm{ZnCl}_{4}\right]$ : Colourless plates were grown at $4{ }^{\circ} \mathrm{C}$ from a mixture of $0.01 \mathrm{M} \mathrm{ZnCl}_{2}$ and $\mathrm{L}$ in $10 \mathrm{M} \mathrm{HCl}$.

Elemental analysis. Elemental analyses were determined by Elemental Microanalysis Ltd and were measured in duplicate.

[HL] $\left[\mathrm{AuCl}_{4}\right]$ : Calculated for $\mathrm{C}_{18} \mathrm{H}_{21} \mathrm{~N}_{2} \mathrm{O}_{2} \mathrm{AuCl}_{4}\left(\mathrm{M}_{\mathrm{r}}=636.14 \mathrm{~g} \mathrm{~mol}^{-1}\right)$ : $\mathrm{C}$, 33.99; H, 3.33; N, 4.40\%. Found: C, 34.18; H, 3.32; N, $4.50 \%$.

[HL] $\left[\mathrm{FeCl}_{4}\right]$ : Calculated for $\mathrm{C}_{18} \mathrm{H}_{21} \mathrm{~N}_{2} \mathrm{O}_{2} \mathrm{FeCl}_{4}\left(\mathrm{M}_{\mathrm{r}}=495.02 \mathrm{~g} \mathrm{~mol}^{-1}\right)$ : $\mathrm{C}, 43.67$; $\mathrm{H}, 4.28 ; \mathrm{N}, 5.66 \%$. Found: $\mathrm{C}, 43.86 ; \mathrm{H}, 4.23 ; \mathrm{N}, 5.80 \%$.

$[\mathrm{HL}]_{2}\left[\mathrm{SnCl}_{6}\right]\left(\mathrm{H}_{2} \mathrm{O}\right)$ : Calculated for $\mathrm{C}_{36} \mathrm{H}_{44} \mathrm{~N}_{4} \mathrm{O}_{5} \mathrm{SnCl}_{6}\left(\mathrm{M}_{\mathrm{r}}=944.18 \mathrm{~g} \mathrm{~mol}^{-1}\right)$ : C, 45.80; H, 4.70; N, 5.93\%. Found: C, 46.31; H, 4.53; N, 6.08\%.

$[\mathrm{HL}]_{2}\left[\mathrm{PtCl}_{6}\right]\left(\mathrm{H}_{2} \mathrm{O}\right)_{2}$ : Calculated for $\mathrm{C}_{36} \mathrm{H}_{46} \mathrm{~N}_{4} \mathrm{O}_{6} \mathrm{PtCl}_{6}\left(\mathrm{M}_{\mathrm{r}}=1038.57 \mathrm{~g} \mathrm{~mol}^{-1}\right)$ : C, $41.63 ; \mathrm{H}, 4.46 ; \mathrm{N}, 5.39 \%$. Found: C, 41.30; H, $4.16 ; \mathrm{N}, 5.60 \%$.

Timed gold precipitation experiments. Solutions of $\mathrm{HAuCl}_{4}(0.01 \mathrm{M})$ were prepared in 2,4 , or $6 \mathrm{M} \mathrm{HCl}$. Solid $\mathrm{L}(0.02 \mathrm{mmol})$ was added to a vial with a magnetic stir bar and the relevant aqueous metal solution $(2 \mathrm{~mL})$ added. The mixture was stirred for between 1 minute* and 55 min after which the stir bar was removed and the vial centrifuged for $5 \mathrm{~min}$. The supernatant was decanted and samples prepared for ICP-OES analysis to measure the uptake of metal. Samples were diluted by $100 \mathrm{x}$ in $2 \%$ nitric acid prior to ICP-OES analysis. ${ }^{*}$ One-minute experiments were not centrifuged and instead stirred for $30 \mathrm{~s}$ before removing the stir bar and allowing any solids to settle for an additional $30 \mathrm{~s}$. A clear $0.1 \mathrm{~mL}$ aliquot was then sampled immediately and prepared for ICP-OES analysis.

Quantitative NMR solubility experiments. ${ }^{1} \mathrm{H}$ NMR spectra were recorded on a Bruker Avance III $400 \mathrm{MHz}$ NMR spectrometer. $2 \mathrm{M}$ and $6 \mathrm{M} \mathrm{HCl}$ solutions were diluted from concentrated $\mathrm{HCl}$ with $\mathrm{D}_{2} \mathrm{O}$. A theoretical $0.1 \mathrm{M}$ solution of $\mathrm{L}$ in $2 \mathrm{M}$ or $6 \mathrm{M} \mathrm{HCl}$ was prepared by adding $\mathrm{L}(0.0178 \mathrm{~g})$ to an NMR tube along with the relevant $\mathrm{HCl} / \mathrm{D}_{2} \mathrm{O}$ solution $(0.55 \mathrm{~mL})$ and $1 \mathrm{M}$ tert-butanol in $\mathrm{D}_{2} \mathrm{O}(0.05 \mathrm{~mL})$ as an internal standard. Any undissolved solids were allowed to settle to the bottom of the NMR tube before acquiring ${ }^{1} \mathrm{H}$ NMR spectra. ${ }^{1} \mathrm{H}$ NMR spectra were acquired for $2 \mathrm{M} \mathrm{HCl}$ solutions between $300-340 \mathrm{~K}$ in $10 \mathrm{~K}$ increments and for $6 \mathrm{M} \mathrm{HCl}$ solutions between $300-320 \mathrm{~K}$ in $10 \mathrm{~K}$ increments; attempts to acquire additional spectra beyond $320 \mathrm{~K}$ for these latter samples were unsuccessful due to excessive line broadening of the spectra and difficulties with sample locking.

Selective stripping experiments with H-tube apparatus. Solid L $(0.2 \mathrm{mmol})$ was added to one side of the H-tube (Supplementary Fig. 11) with a stir bar. The metalcontaining aqueous solution $(2 \mathrm{~mL})$ was then added to the solids and the mixture stirred for $1 \mathrm{~h}$ at room temperature at $500 \mathrm{rpm}$, after which it was passed through the glass frit of the $\mathrm{H}$-tube with the aid of compressed air or $\mathrm{N}_{2}$ gas (See Supplementary Movie 1). The filtrate was collected for ICP-OES analysis to determine metal uptake. The solids were subsequently washed with $2 \mathrm{M} \mathrm{HCl}(3 \times 2 \mathrm{~mL})$ for $30 \mathrm{~min}$, with each $2 \mathrm{~mL}$ solution being passed through the glass frit of the $\mathrm{H}$-tube. The solids were then washed with ultrapure deionised water $(5 \times 2 \mathrm{~mL})$ in the same manner. The use of a H-tube allows for all solids to be retained in the same vessel to minimise any loss of metal due to material transfer. This procedure was repeated in duplicate.

Purity of recovered gold from $\mathbf{0 . 0 1} \mathbf{M}$ mixed metal solution. A solution of $\mathrm{HAuCl}_{4}$ in ultrapure deionised water resulting from a load/strip cycle from a $0.01 \mathrm{M}$ mixed-metal solution was reduced by addition of sodium metabisulfite. The resulting solids were filtered and dried. $1.7 \mathrm{mg}$ of solids was re-dissolved in aqua regia $(3 \mathrm{~mL})$ and diluted 100x for ICP-OES analysis. The purity of the reduced Au was found to be $97.04 \%$

Recycling experiments. A solution of $\mathrm{HAuCl}_{4}(0.01 \mathrm{M}, 2 \mathrm{~mL})$ in $6 \mathrm{M} \mathrm{HCl}$ was stirred with $\mathrm{L}(0.059 \mathrm{~g}, 0.02 \mathrm{mmol})$ in a vial for $15 \mathrm{~min}$. The mixture was centrifuged and the supernatant liquors pipetted from the solids, after which ultrapure deionised water $(5 \times 2 \mathrm{~mL})$ was added and the mixture stirred for $15 \mathrm{~min}$. The mixture was then centrifuged and the solution pipetted from the solids for each wash cycle. This load/strip procedure was repeated three times.

ICP-OES analysis. Quantitative metal analysis was carried out on a Perkin Elmer Optima 5300DC Inductively Coupled Plasma Optical Emission Spectrometer. Samples in $2 \%$ nitric acid were taken up by a peristaltic pump at a rate of $1.3 \mathrm{~mL} \mathrm{~min}^{-1}$ into a Gem Tip cross-flow nebuliser and a glass cyclonic spray chamber. Argon plasma conditions were $1500 \mathrm{~W}$ RF forward power and argon gas flows of 12, 1.0, and $0.6 \mathrm{~L} \mathrm{~min}^{-1}$ for plasma, auxiliary, and nebuliser flow, respectively. ICP-OES calibration standards were obtained from VWR International, Merck Millipore, or SigmaAldrich. Selected emission wavelengths are detailed in Supplementary Table 8. Data are rounded to 3 significant figures after incorporating the appropriate dilution factors (typically 100x unless otherwise stated).
ICP-MS analysis. ICP-MS analysis was carried out by Agilent LTD on an Agilent 7850 Single Quadrupole Inductively Coupled Plasma Mass Spectrometer. Samples in $2 \%$ nitric acid were taken up by a peristatic pump at a rate of $0.3 \mathrm{rps}$ into a MicroMist nebuliser and a quartz Scott type spray chamber. Argon plasma conditions were $1550 \mathrm{~W}$ RF power and gas flows of $15,1.07$, and $0.9 \mathrm{~L} \mathrm{~min}^{-1}$ for plasma, auxiliary, and nebuliser flow, respectively.

UV-Vis analysis. UV-Vis spectra of $[\mathrm{HL}]\left[\mathrm{AuCl}_{4}\right]$ were recorded in acetonitrile in quartz cuvettes $\left(1 \mathrm{~cm}^{3}\right.$ path length) on a Shimadzu UV-1900 UV-VIS spectrophotometer (Supplementary Fig. 5). A $1 \mathrm{mM}$ stock solution was prepared by dissolving dry $[\mathrm{HL}]\left[\mathrm{AuCl}_{4}\right](6.4 \mathrm{mg})$ in acetonitrile. This solution was then diluted to lower concentrations by serial dilution to obtain measurable UV-Vis spectra.

X-ray crystallography. X-ray crystallographic data were collected at $100 \mathrm{~K}$ or $120 \mathrm{~K}$ on an Oxford Diffraction Excalibur diffractometer using graphite monochromated Mo- $\mathrm{K}_{\alpha}$ radiation equipped with an Eos CCD detector $(\lambda=0.71073 \AA)$, or at $100 \mathrm{~K}$ or $120 \mathrm{~K}$ on a Supernova, Dual, $\mathrm{Cu}$ at Zero Atlas diffractometer using $\mathrm{Cu}-\mathrm{K}_{\alpha}$ radiation $(\lambda=1.5418 \AA)$, or at $100 \mathrm{~K}$ on a Bruker APEX-II CCD diffractometer using graphite monochromated Mo- $\mathrm{K}_{\alpha}$ radiation $(\lambda=0.71073 \AA)$ Structures were solved using ShelXT direct methods or intrinsic phasing and refined using a full-matrix least-square refinement on $|F|^{2}$ using ShelXL ${ }^{39-41}$. All programs were used within the Olex suites ${ }^{42}$. All non-hydrogen atoms were refined with anisotropic displacement parameters. $\mathrm{H}$-atom parameters were constrained to parent atoms and refined using a riding model except $\mathrm{H} 1$ and $\mathrm{H} 2$, which were located in the difference Fourier maps and refined with isotropic displacement parameters. All X-ray crystal structures were analysed and illustrated using Mercury 4.1.0. X-ray data are presented in Supplementary Tables 9-14.

NCI plots. All structures were optimised (atom-only) using CASTEP17.21 ${ }^{43}$, with on-the-fly pseudopotentials and a plane-wave energy cut-off of $750 \mathrm{eV}$, coupled to the PBE DFT functional and TS dispersion correction scheme ${ }^{44-46}$. Brillouin zone sampling was $0.05 \AA^{-1}$. Geometry convergence criteria: energy tolerance $=2 \times$ $10^{-5} \mathrm{eV}$ atom $^{-1}$, max force $=0.05 \mathrm{eV}^{-1}$, max atomic displacement $=2 \times 10^{-3}$ $\AA$. Following geometry optimisation, charge density cube files were generated using the CASTEP2CUBE utility, and subsequently used to generate non-covalent interaction (NCI) plots using the CRITIC2 code ${ }^{47-49}$. The graphical output from CRITIC2 was processed using VMD1.9.3 ${ }^{50}$ and Origin2019.

Powder X-ray diffraction. Powder X-ray Diffraction (PXRD) data were collected on a sample of $[\mathrm{HL}]\left[\mathrm{AuCl}_{4}\right]$ precipitated by the addition of $\mathrm{L}(5.9 \mathrm{mg}, 0.02 \mathrm{mmol})$ to a solution of $\mathrm{HAuCl}_{4}(0.01 \mathrm{M})$ in $\mathrm{HCl}(6 \mathrm{M})$ using a Bruker D2 phaser diffractometer in reflection geometry with $\mathrm{Cu}$ Ka radiation $(\lambda=1.541 \AA$ ). A LynxEye position sensitive detector was used to collect data over the $2 \theta$ range $6-65^{\circ}$ for $15 \mathrm{~min}$. Sample preparation involved grinding powder samples, mixing with acetone, and depositing a thin layer on a zero-background silicon (911) substrate. The data were analysed using a Pawley fitting routine in the Topas Academic (version 6) software suite.

\section{Data availability}

X-ray data are available free of charge from the Cambridge Crystallographic Data Centre (https://www.ccdc.cam.ac.uk/data_request/cif) under reference numbers CCDC-2084239 $\left([\mathrm{HL}]\left[\mathrm{AuCl}_{4}\right]\right), \mathrm{CCDC}-2084236$ ([HL][ $\left.\left[\mathrm{AuBr}_{4}\right]\right), \mathrm{CCDC}-2084238\left([\mathrm{HL}]\left[\mathrm{FeCl}_{4}\right]\right), \mathrm{CCDC}-$ $2084235\left(\left[\mathrm{HL}_{2}\left[\mathrm{SnCl}_{6}\right]\left(\mathrm{H}_{2} \mathrm{O}\right)\right), \mathrm{CCDC}-2084240\left(\left[\mathrm{HL}_{2}\left[\mathrm{PtCl}_{6}\right]\left(\mathrm{H}_{2} \mathrm{O}\right)\right), \mathrm{CCDC}-2084241\right.\right.$ $[\mathrm{HL}]\left[\left(\mathrm{H}_{3} \mathrm{O}\right)\left(\mathrm{H}_{2} \mathrm{O}\right)_{2}\right]\left[\mathrm{CoCl}_{4}\right]$, and CCDC-2084237 $[\mathrm{HL}]\left[\mathrm{H}_{3} \mathrm{O}\left(\mathrm{H}_{2} \mathrm{O}\right)_{2}\right]\left[\mathrm{ZnCl}_{4}\right]$. The quantitative metal analyses and NMR data are available in the Edinburgh DataShare repository using the identifier https://doi.org/ $10.7488 / \mathrm{ds} / 3115^{51}$. The authors declare that all other data supporting the findings of this study are available within the paper and its supplementary information files.

Received: 11 June 2021; Accepted: 12 October 2021; Published online: 29 October 2021

\section{References}

1. Izatt, R. Metal Sustainability: Global Challenges, Consequences, and Prospects (ed. Izatt, R. M.) (John Wiley \& Sons, Ltd., 2016).

2. Forti, V., Baldé, C. P., Kuehr, R. \& Bel, G. The Global E-waste Monitor 2020: Quantities, flows and the circular economy potential., (United Nations University (UNU)/United Nations Institute for Training and Research (UNITAR) - co-hosted SCYCLE Programme, International Telecommunication Union (ITU) \& International Solid Waste Association (ISWA), Bonn/Geneva/Rotterdam, 2020).

3. Reck, B. K. \& Graedel, T. E. Challenges in metal recycling. Science 337, 690-695 (2012).

4. Eggert, R. G. Minerals go critical. Nat. Chem. 3, 688-691 (2011). 
5. Adams, M. D. Gold ore Processing: Project Development and Operations (Elsevier, 2016).

6. Medina, D. \& Anderson, C. G. A review of the cyanidation treatment of copper-gold ores and concentrates. Metals 10, 897 (2020).

7. Zolnikov, T. R. \& Ramirez Ortiz, D. A systematic review on the management and treatment of mercury in artisanal gold mining. Sci. Total Environ. 633, 816-824 (2018).

8. Kiddee, P., Naidu, R. \& Wong, M. H. Electronic waste management approaches: an overview. Waste Manag. 33, 1237-1250 (2013).

9. Rao, M. D., Singh, K. K., Morrison, C. A. \& Love, J. B. Challenges and opportunities in the recovery of gold from electronic waste. RSC Adv. 10, 4300-4309 (2020).

10. Hagelüken, C. \& Corti, C. W. Recycling of gold from electronics: cost-effective use through 'design for recycling'. Gold. Bull. 43, 209-220 (2010).

11. Awasthi, A. K., Li, J., Koh, L. \& Ogunseitan, O. A. Circular economy and electronic waste. Nat. Electron. 2, 86-89 (2019).

12. Velenturf, A. P. M. \& Jopson, J. S. Making the business case for resource recovery. Sci. Total Environ. 648, 1031-1041 (2019).

13. Izatt, R. M., Izatt, S. R., Bruening, R. L., Izatt, N. E. \& Moyer, B. A. Challenges to achievement of metal sustainability in our high-tech society. Chem. Soc. Rev. 43, 2451-2475 (2014).

14. Bigum, M., Brogaard, L. \& Christensen, T. H. Metal recovery from high-grade WEEE: a life cycle assessment. J. Hazard. Mat. 207-208, 8-14 (2012).

15. Nelson, J. J. M. et al. High-throughput screening for discovery of benchtop separations systems for selected rare earth elements. Commun. Chem. 3, 7 (2020).

16. Nelson, J. J. M. \& Schelter, E. J. Sustainable inorganic chemistry: metal separations for recycling. Inorg. Chem. 58, 979-990 (2019).

17. Shaffer, C. C. \& Smith, B. D. Macrocyclic and acyclic supramolecular elements for co-precipitation of square-planar gold(III) tetrahalide complexes. Org. Chem. Front. 8, 1294-1301 (2021).

18. Verma, A., Kore, R., Corbin, D. R. \& Shiflett, M. B. Metal recovery using oxalate chemistry: a technical review. Ind. Eng. Chem. Res. 58, 15381-15393 (2019).

19. Lewis, A. E. Review of metal sulphide precipitation. Hydrometallurgy 104, 222-234 (2010).

20. Mon, M. et al. Selective gold recovery and catalysis in a highly flexible methionine-decorated metal-organic framework. J. Am. Chem. Soc. 138, 7864-7867 (2016).

21. Sun, D. T., Gasilova, N., Yang, S., Oveisi, E. \& Queen, W. L. Rapid, selective extraction of trace amounts of gold from complex water mixtures with a metal-organic framework (MOF)/polymer composite. J. Am. Chem. Soc. 140, 16697-16703 (2018).

22. Hong, Y. et al. Precious metal recovery from electronic waste by a porous porphyrin polymer. Proc. Nat. Acad. Sci. USA 117, 16174 (2020).

23. Wu, Y., Fang, Q., Yi, X., Liu, G. \& Li, R.-W. Recovery of gold from hydrometallurgical leaching solution of electronic waste via spontaneous reduction by polyaniline. Prog. Nat. Sci. 27, 514-519 (2017).

24. Lahtinen, E. et al. Selective recovery of gold from electronic waste using 3Dprinted scavenger. ACS Omega 2, 7299-7304 (2017).

25. Okesola, B. O., Suravaram, S. K., Parkin, A. \& Smith, D. K. Selective extraction and in situ reduction of precious metal salts from model waste to generate hybrid gels with embedded electrocatalytic nanoparticles. Angew. Chem. Int. Ed. 55, 183-187 (2016).

26. Liu, Z. et al. Selective isolation of gold facilitated by second-sphere coordination with $\alpha$-cyclodextrin. Nat. Commun. 4, 1855 (2013).

27. Liu, Z. et al. Cation-dependent gold recovery with $\alpha$-cyclodextrin facilitated by second-sphere coordination. J. Am. Chem. Soc. 138, 11643-11653 (2016).

28. Chen, L.-X. et al. Outer surface interactions to drive cucurbit[8]uril-based supramolecular frameworks: possible application in gold recovery. Chem. Commun. 55, 14271-14274 (2019).

29. Lin, R.-L. et al. Selective recovery and detection of gold with cucurbit[n]urils $(\mathrm{n}=5-7)$. Inorg. Chem. 59, 3850-3855 (2020).

30. $\mathrm{Wu}, \mathrm{H}$. et al. High-efficiency gold recovery using cucurbit[6]uril. ACS Appl. Mater. Interfaces 12, 38768-38777 (2020).

31. $\mathrm{Wu}, \mathrm{H}$. et al. Selective separation of hexachloroplatinate(IV) dianions based on exo-binding with cucurbit[6] uril. Angew. Chem. Int. Ed. 60, 17587-17594 (2021).

32. Shaffer, C. C., Liu, W., Oliver, A. G. \& Smith, B. D. Supramolecular paradigm for capture and co-precipitation of gold(III) coordination complexes. Chem. Eur. J. 27, 751-757 (2021).

33. Nag, A., Islam, M. R. \& Pradeep, T. Selective extraction of gold by niacin. ACS Sustain. Chem. Eng. 9, 2129-2135 (2021).

34. Doidge, E. D. et al. A simple primary amide for the selective recovery of gold from secondary resources. Angew. Chem. Int. Ed. 55, 12436-12439 (2016).

35. Doidge, E. D. et al. Evaluation of simple amides in the selective recovery of gold from secondary sources by solvent extraction. ACS Sustain. Chem. Eng. 7, 15019-15029 (2019).
36. Yang, C., Tan, Q., Liu, L., Dong, Q. \& Li, J. Recycling tin from electronic waste: a problem that needs more attention. ACS Sustain. Chem. Eng. 5, 9586-9598 (2017)

37. Narita, H., Kasuya, R., Suzuki, T., Motokawa, R. \& Tanaka, M. in Encyclopedia of Inorganic and Bioinorganic Chemistry 1-28 (John Wiley and Sons, Ltd., 2021).

38. Kaufmann, L. et al. Substituent effects on axle binding in amide pseudorotaxanes: comparison of NMR titration and ITC data with DFT calculations. Org. Biomol. Chem. 10, 5954-5964 (2012).

39. Sheldrick, G. A short history of SHELX. Acta Crystallogr. Sect. A 64, 112-122 (2008).

40. Sheldrick, G. SHELXT-integrated space-group and crystal-structure determination. Acta Crystallogr. Sect. A 71, 3-8 (2015).

41. Sheldrick, G. Crystal structure refinement with SHELXL. Acta Crystallogr. Sect. C. 71, 3-8 (2015).

42. Dolomanov, O. V., Bourhis, L. J., Gildea, R. J., Howard, J. A. K. \& Puschmann, H. OLEX2: a complete structure solution, refinement and analysis program. J. Appl Crystallogr. 42, 339-341 (2009).

43. Clark, S. J. et al. First principles methods using CASTEP. Z. Kristallograph. 220, 567-570 (2005).

44. McNellis, E. R., Meyer, J. \& Reuter, K. Azobenzene at coinage metal surfaces: Role of dispersive van der Waals interactions. Phys. Rev. B 80, 205414 (2009).

45. Perdew, J. P., Burke, K. \& Ernzerhof, M. Generalized gradient approximation made simple. Phys. Rev. Lett. 77, 3865-3868 (1996).

46. Tkatchenko, A. \& Scheffler, M. Accurate molecular Van der Waals interactions from ground-state electron density and free-atom reference data. Phys. Rev. Lett. 102, 073005 (2009).

47. Contreras-García, J. et al. NCIPLOT: a program for plotting noncovalent interaction regions. J. Chem. Theory Comput. 7, 625-632 (2011).

48. Otero-de-la-Roza, A., Blanco, M. A., Pendás, A. M. \& Luaña, V. Critic: a new program for the topological analysis of solid-state electron densities. Comput. Phys. Commun. 180, 157-166 (2009).

49. Otero-de-la-Roza, A., Johnson, E. R. \& Luaña, V. Critic2: a program for realspace analysis of quantum chemical interactions in solids. Comput. Phys. Commun. 185, 1007-1018 (2014).

50. Humphrey, W., Dalke, A. \& Schulten, K. VMD: visual molecular dynamics. J. Mol. Graph. 14, 33-38 (1996).

51. Kinsman, L. M. M., Ngwenya, B. T., Morrison, C. A. \& Love, J. B. Gold precipitation by diamides - ICP-OES and NMR data, Edinburgh University DataShare, https://doi.org/10.7488/ds/3115 (2021).

\section{Acknowledgements}

This research was funded by the University of Edinburgh and the Natural Environment Research Council E3-DTP, grant number NE/L002558/1 (PhD studentship for L.M.M.K. received by J.B.L.). We thank the Edinburgh Computer and Data Facility for access to high-performance computing. We also thank Dr Caroline Kirk at the University of Edinburgh for recording and analysing the powder X-ray diffraction data and Dr Gary Nichol at the University of Edinburgh for his help with single-crystal X-ray crystallography.

\section{Author contributions}

L.M.M.K. carried out all of the experimental work and analytical characterisation, spectroscopic analysis, and X-ray crystallography. C.A.M. carried out the computational studies. L.M.M.K., C.A.M., B.T.N. and J.B.L. analysed the data and wrote the manuscript. C.A.M., B.T.N., and J.B.L. directed the research.

\section{Competing interests}

The research described in this manuscript forms the basis of the UK patent application: L. M. M. Kinsman, B. T. Ngwenya, C. A. Morrison, J. B. Love, $\mathrm{N}^{\circ} 2110701.6$ (2021). All authors declare no other competing interests.

\section{Additional information}

Supplementary information The online version contains supplementary material available at https://doi.org/10.1038/s41467-021-26563-7.

Correspondence and requests for materials should be addressed to Jason B. Love.

Peer review information Nature Communications thanks Adrian Whitwood and the other, anonymous, reviewer(s) for their contribution to the peer review of this work.

Reprints and permission information is available at http://www.nature.com/reprints

Publisher's note Springer Nature remains neutral with regard to jurisdictional claims in published maps and institutional affiliations. 
(c) (i) Open Access This article is licensed under a Creative Commons Attribution 4.0 International License, which permits use, sharing, adaptation, distribution and reproduction in any medium or format, as long as you give appropriate credit to the original author(s) and the source, provide a link to the Creative Commons license, and indicate if changes were made. The images or other third party material in this article are included in the article's Creative Commons license, unless indicated otherwise in a credit line to the material. If material is not included in the article's Creative Commons license and your intended use is not permitted by statutory regulation or exceeds the permitted use, you will need to obtain permission directly from the copyright holder. To view a copy of this license, visit http://creativecommons.org/ licenses/by/4.0/.

(C) The Author(s) 2021 